\title{
Unique Natural Objects of Mountain Landscapes of the Chechen Republic
}

\section{Zaburayeva Kh.Sh.}

Department of Geology, Geophysics and Geoecology

Complex Research Institute named after Kh.I. Ibragimov,

Russian Academy of Sciences,

Institute of Oil and Gas

Grozny State Oil Technical University

named M.D. Millionshchikov

Grozny, Russia

eveggne@mail.ru

Gayrabekov U.T.

Department of Geology, Geophysics and Geoecology Complex Research Institute named Kh.I. Ibragimov,

Russian Academy of Sciences,

Faculty of Geography and Geoecology

Chechen State University

Grozny, Russia

gairabekov_u@mail.ru

Daukayev Asl.A.

Department of Geology, Geophysics and Geoecology Complex Research Institute named Kh.I. Ibragimov,

Russian Academy of Sciences

Department of Earth Sciences

Academy of Sciences of the Chechen Republic

Grozny, Russia

daykaev@mail.ru

\author{
Gatsayeva L.S. \\ Department of Geology, Geophysics and Geoecology \\ Complex Research Institute named Kh.I. Ibragimov, \\ Russian Academy of Sciences \\ Grozny, Russia \\ gls69@yandex.ru
}

\author{
Dzhabrailov S.-E.M. \\ Faculty of Geography and Geoecology \\ Chechen State University \\ Grozny, Russia \\ 89298897328@mail.ru
}

\author{
Sediyeva M.B. \\ Department of Geology, Geophysics and Geoecology \\ Complex Research Institute named after Kh.I. Ibragimov, \\ Russian Academy of Sciences \\ Grozny, Russia \\ milann_s@mail.ru
}

\author{
Abumuslimova I.A. \\ Department of Biological and Medical Studies \\ Academy of Sciences of the Chechen Republic \\ Grozny, Russia \\ indira anChechen Republic@mail.ru
}

\begin{abstract}
The paper considers unique natural objects within the mountain territory of the Chechen Republic (hydrological, paleontological, biological, etc.). It provides information on natural objects qualified as nature sanctuaries, as well as describes unique natural objects (including, paleontological and stratigraphic) recommended for inclusion into the list of nature sanctuaries. The paper also reveals modern problems of reserve management and studies in the region and gives recommendations regarding their solution.
\end{abstract}

Keywords-Chechen Republic, nature sanctuaries, protected areas, mountain landscapes, wildlife reserves, attraction, recreation, environmental framework.

\section{INTRODUCTION}

The Protected Areas (PA) play a key role in ensuring the conservation of natural landscapes, biodiversity and in implementing the principles of sustainable development accepted by the world community in general. The development of protected areas contributes to the conservation of resources, including unique and nonrenewable, which value steadily increases in the modern world. Therefore, the study of the state, use and prospects of PA system development are still relevant around the world [10, 23, 23]. They become ever more relevant in the conditions of sensitive mountain ecosystems that require a particular approach to their study and planning $[3,7,15,22,27]$. Over the recent years, the areas 
of protected territories and water areas have extended significantly around the world. It shall be recognized that the formalistic approach to their development will not foster the achievement of target objectives [19].

Initially PA were created to maintain the natural state of landscapes under the condition of minimum human engagement. However, taking into account the global environmental changes, transformation of some natural landscapes into their anthropogenic modifications and in general the increasing role of the anthropogenic factor, it is impossible to consider the protected areas as isolated territories purely serving the tasks of nature protection [16]. PA also ensure the fulfillment of social and economic tasks. It is impossible to overestimate the PA role in providing the humankind with ecosystem services $[18,20,26]$. The term "provider functions" is also applied for their designation.

Since the times of the primitive communal system, people have been exerting a significant environmental impact on nature. However, this impact with rudimentary tools in that time and during the subsequent eras was insignificant in comparison with the latest period - the era of scientific and technical progress when the humankind (which has grown from 1-2 billion to 7 billion over the last centuries) equipped with powerful machinery is developing vast territories (agricultural, hydraulic, irrigative and other objects) and recovering billions of tons of various subsoil minerals. The socalled problem of "wilderness" (also translated as "wildlife area", "wild nature", "sanctuary") is opposed to the problem of landscape anthropogenic condition.

\section{METHODS AND MATERIALS}

The methodological basis of the study included the following methods: system, historical, statistical analyses, as well as the field study. The study was based on the field studies of the group of authors and the reports of the Ministry of Natural Resources and Environmental Protection of the Chechen Republic, ARGUN nature reserve.

\section{RESULTS}

The expansion of tasks solved by PA, their inclusion into social and economic systems as a full-fledged participant of social and economic development and a cornerstone of their sustainable development are being gradually tackled throughout the entire world. It mainly refers to the concept of eco-tourism (scientific and educational) tourism, which gained its wide recognition abroad. Eco-tourism implies the insight into nature, customs and traditions of local ethnic communities; minimum negative impact on natural landscapes and objects of historical and cultural heritage; assistance to conservation of nature and local sociocultural environment; environmental education of tourism industry participants (including recreants and local population); economic efficiency of their functions.

Under the condition of rational behavior of recreants, the tourist activity within protected areas may contribute to their sustainable development [25]. This, in turn, implies high degree of awareness of recreants concerning rules of conduct within protected areas and their importance for sustainable development of humankind.

Tourism and recreation activities within protected areas shall not conflict or cause damage to their fundamental functions - nature protection and research. The influence of recreation activity on wild nature and protected areas within recreation ecology as scientific field has been studied for over 80 years. Such studies focus on the analysis of the recreants' impact on vegetation, soil cover, water resources and other components of natural landscapes [20]. They allow revealing weaknesses, threats and risks in the depletion of biodiversity, degradation of recreation territories and objects, as well as minimizing or preventing the detrimental effect. Numerous studies of the last years confirm the interdependence and interconditionality of tourist industry and living standards of the population $[17,21]$. One of key concepts of tourism and recreation industry is "attraction". This may refer to landscapes or geocomplexes, biota, mineral waters and therapeutic muds, places of life and activity of historic figures, etc. [11].

The recreation sphere is a highly profitable branch of economy having important social value and demanding (for long-term efficient functioning) strive towards the balance between social and economic interests and nature protection tasks. Russia has a huge potential presented by natural landscapes, national and natural parks, objects of the world natural heritage, etc. for the development of eco-tourism [21]. It is mainly concentrated in the Caucasus region $[4,6,9]$. The maximum landscape variety of Russia is concentrated in mountain regions of Russia [1], and the greatest landscape variety typical for mountain regions is located within the territory of the studied object (Chechen Republic) [5].

According to various estimates, over $10 \%$ of the Russian territory belong to protected areas [3], which is a powerful tool of rational environmental management and the natural balance in general. A considerable part of highlands of the North Caucasus can be considered "wilderness". The mineral waters of the Caucasus, dozens of wildlife areas, national parks, etc. belong to the category of protected areas. A special attention is paid to the protection of forests, biological diversity (Red Book) and other components of the environment. Besides, such important components of natural and territorial complexes as bedrock exposure are almost neglected. In certain countries (for instance, in England) the latter one is paid the same careful attention as other components.

Besides national and natural parks, wildlife areas, and reserves traditionally occupying considerable territories, the nature sanctuaries are also characterized by high recreation potential. According to Art. 25 of the Federal Law On Protected Areas No. 33-FZ of March 14, 1995 (as amended on 03.08.2018), such protected areas include "unique, nonrenewable, valuable natural complexes and natural and man-made objects from their environmental, scientific, cultural and esthetic perspective". They may have both the federal and the regional status.

Besides the above law, the legal framework of PA development in the Chechen Republic (CR) includes the following: Federal Law On Environmental Protection No. 7- 
FZ of January 10, 2002, Law of the Chechen Republic On Environmental Protection No. 10 of July 4, 2006, Law of the Chechen Republic On Protected Areas of the Chechen Republic No. 40 of December 4, 2006. It is worth noting here the Resolution of the Government of the Chechen Republic On Nature Sanctuaries of the Chechen Republic No. 125 of 14.11.2006, according to which 43 unique natural objects in the territory of the Chechen Republic were awarded the status of regional nature sanctuaries. They include over 20 objects located in the mountains of the republic: lakes - Bezenoy-Am, Galanchozh, Kezenoy-Am; groundwater springs - ChantyArgunsky fresh water spring, Kuroysky carbonated spring; waterfalls - Vashindaroy, Harachoy; mineral springs - Oil hot spring, Epkhe, springs in the district of the Melchkhi and Chanty-Argun villages; oil springs - Simsirsky, Yaryksuysky; geomorphological -Arch and Brothers residual mountains; botanical - Common yew (Simsir village), Caucasian lime park (Vedeno village), Makazhoyevsky pine wood (Vedeno district), Radde birch grove (Itum-Kalinsky district), Bamut and Achkhoy-Martanovsky pine groves (AchkhoyMartanovsky district), Scotch pine grove (Nozhay-Yurtovsky district). The condition of protected areas and the environment in general is reflected in annual reports of the Ministry of Natural Resources and Environmental Protection of the Chechen Republic [2].

The total PA area of the Chechen Republic is 316.89 thousand hectares (or 19.6\% of the total area of the region), including 9 wildlife areas (one federal and eight regional) and 43 nature sanctuaries [14]. The majority of PA is located in the zone of mountain forests and meadows, including the largest state biological wildlife areas: Sovietsky, Vedensky, part of Urus-Martanovsky and Shalinsky wildlife areas (Figure 1) $[14]$

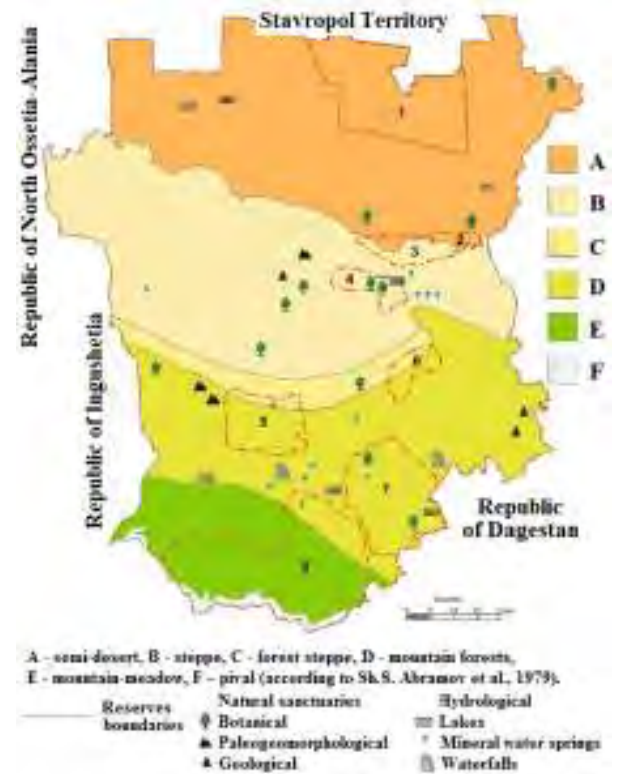

Fig. 1. Protected areas of the Chechen Republic in the system of landscape zoning [14]: 1 - Stepnoy, 2 - Parabochevsky, 3 - Bragunsky, 4 - Argunsky, 5 - Urus-Martanovsky, 6 - Shalinsky, 7 - Vedensky, 8 - Sovetsky (federal).

The resolution of the Government of the Chechen Republic No. 77 of 04.04.2017 (as amended on 07.12.2018) adopted the program on Social and economic development of mountain territories: Vedensky, Itum-Kalinsky, NozhayYurtovsky, Shatoisky, Sharoysky municipal districts of the Chechen Republic for 2017-2020. The given study focuses on the most unique natural objects, which correspond to the status of nature sanctuaries.

The existing PA shall be united into a single network (environmental framework) thus contributing to the conservation of biodiversity, wildlife species and their native habitats within fragmented natural territories and transformed landscapes. The processes influencing the biological diversity are not limited to boundaries of the states or regions. There is a need to strive towards the international system of coordination and integration, development of the Emerald Network consisting of "areas of special conservation interest" to preserve the natural landscapes $[8,14]$.

The structure of recreation potential of the Chechen Republic is deeply focused on hydrorecreation formed by the dense river network (mainly in foothill and mountain parts), lakes, waterfalls, mineral springs thus creating opportunities for broad-scale development of recreation activity in the region [13]. The only factor limiting water tourism is lack of access to the sea. Multiple waterfalls on mountain rivers of the republic are very picturesque. For example, the Vashindaroy waterfall (height $-10 \mathrm{~m}$ and width - up to $2 \mathrm{~m}$ ) was recognized a nature sanctuary in 1980 (Fig. 2). It is located on the southeast suburb of Vashindaroy village in the valley of the Varanda River (the Chanty-Argun tributary). The waterfall is easily accessible and until 1990s it was often visited by tourists. The waterfall on the Akhkichu River tributary is about $50 \mathrm{~m}$ high and is located $5-7 \mathrm{~km}$ to the south of the Chechel-hi village of Nozhay-Yurtovsky district.

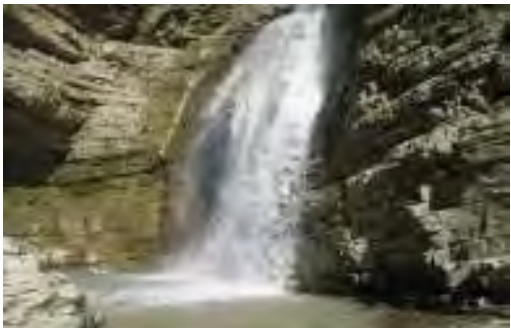

Fig. 2. Vashindaroy waterfall

The Bukkuzinsky waterfall is located $15-16 \mathrm{~km}$ from the Ulus-Kert village on the right coast of the Sharo-Argun River [13]. This waterfall impresses with its beauty and magnificence. The water falls from about $80 \mathrm{~m}$ high mountain wall. There are a few sulfur springs near the waterfall. One of the deepest caves of the Chechen Republic - Shaki-ekhk-hekh (sulfur river cave) is also located here $(100 \mathrm{~m}$ downstream from the Argun River). The sulfur spring producing $100 \mathrm{l} / \mathrm{s}$ passes along the cave. At the exposure, the sulfur river flows into the Sharo-Argun River. The length of the main corridor of the cave reaches $240 \mathrm{~m}$. According to estimates, Bukkuzinsky hydrological objects have important recreation and balneological value. In particular, they can be used for the treatment of digestive tract, locomotion system and other diseases. According to the study conducted in 2017 by scientists of the Ufa Institute of Biology - RAS, the Shaki- 
ekhk-hekh cave is unique in its own way. Sulfur bacteria forming bacterial mats are still being developed in the cave. In the Bukuzi area throughout 800-1000 $\mathrm{m}$ there are 12 hydrosulfuric springs with the total debit of 7 thousand liters a day. Approximately 100 meters higher up the Sharo-Argun River, 4-5 $\mathrm{m}$ above the river edge there is the Magomed-hekh cave with hydrosulfuric lake. The size of the lake is $12-45 \mathrm{~m}$, depth $-1.8-2.0 \mathrm{~m}$. The sulfur spring with the total debit of 1800-2000 liters a day is flowing from the cave.

The Nikhaloysky waterfalls and the Nokhchi-Keloysky waterfall near the settlement having the same name on the right tributary of the Chanty-Argun River deserve special attention. The first constitute the entire complex of waterfalls from small (2-10 m high) to heavy waterfalls (12, 15 and $32 \mathrm{~m}$ high). The surrounding landscapes (canyons, cliffs, boulders) create an impression of virgin purity and natural beauty of local places. The uppermost point of this complex opens a view on the Argun Gorge making the heart soar. The NokhchiKeloysky waterfall, which height reaches $74 \mathrm{~m}$, is located on the left tributary of the Keloy-akhk River $1 \mathrm{~km}$ eastwards from the Nokhch-Keloy village. There is a walking trail to the waterfall.

Another important hydrorecreation resource of Chechnya includes its health improving and water touring lakes. The recreants are attracted by the proximity of lakes (damming, landslide, glacial, karst and other lakes) to settlements and their fast warming capacity. Besides, they are more ecologically vulnerable in comparison with large water objects. It is also worth mentioning the Kezenoy-Am Lake the largest mountain reservoir in the North Caucasus with the area of about $2 \mathrm{~km}^{2}$, which was declared a nature sanctuary in 1978 [13]. It surpasses the famous Ritsa Lake in size. The lake was formed as a result of impounded valley of the Khorsuma and Kaukhi Rivers being the main source of its nourishment. It has no surface water supply. The lake is located at the height of $1870 \mathrm{~m} \mathrm{A.S.L.} \mathrm{on} \mathrm{the} \mathrm{slope} \mathrm{of} \mathrm{the} \mathrm{Andi} \mathrm{Ridge} \mathrm{at} \mathrm{the} \mathrm{border}$ of Chechnya with Dagestan within the area of mountain meadows and steppes. It was the place for the Olympic base of the USSR national rowing team. The area of the lake is characterized by favorable climatic conditions: sunny weather prevails throughout the year, no heavy rainfall. Air is clear and transparent. There is a large variety of fauna. The Eyzenam trout included into the Red Book of Russia is considered one of the landmarks of the lake.

In 2015, the Kezenoy-Am tourist and recreation complex, including a hotel, a restaurant, a sauna, a sport center, a boat station, a pier, a shooting gallery, shelter sheds and lodges, ropeways, bike and quad tours for tourists, was opened here. It is also planned to build a ski resort for children here (Fig. 3).

Among other mountain lakes, there are the Zumsoyskoye and Gukhoyskoye lakes. The first one is located in the area of subalpine meadows at the height of about $1800 \mathrm{~m} \mathrm{A.S.L.} \mathrm{on}$ the right slope of the Kyashta River 8-9 km southeast from the Zumsoy village. Its size reaches $180-100 \mathrm{~m}$, and depth $-10-12$ $\mathrm{m}$. At present, the lake is overgrown with cane. The Gukhoysky Lake is located southeast from the Gukhoy village at the height of $1245 \mathrm{~m} \mathrm{A.S.L.} \mathrm{The} \mathrm{lake} \mathrm{has} \mathrm{an} \mathrm{oval} \mathrm{form} \mathrm{and}$ its size reaches $50 \times 100 \mathrm{~m}$. According to preliminary data, it was formed as a result of karst processes. The lake is located in the area of subalpine meadows in a very picturesque place.

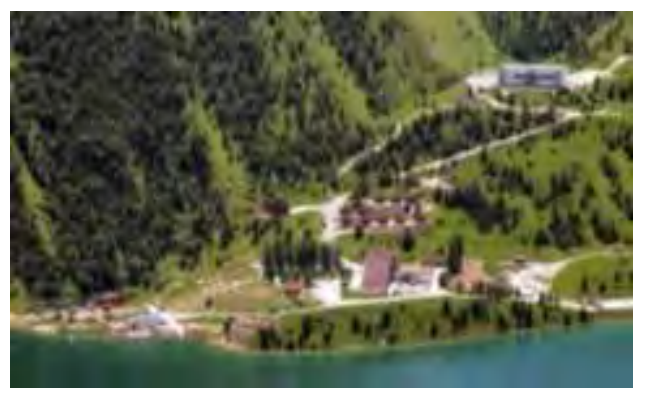

Fig. 3. Kezenoy-Am sports and tourist complex.

Morphogenetic and hydrological conditions of mountain lakes of the Caucasus are attributed to tectonic, lithologic and geodynamic features of the Caucasian region. The lakes of the Caucasus are generally characterized by a certain genetic zonation. Thus, the mountain part is characterized by tectonic lakes, the average elevation - by karst, damming and landslide lakes mainly, and the lowlands - by aeolian and flood plain lakes. The mountain lakes of the Chechen Republic (especially Kezenoy-Am Lake) have high recreation potential and their further study represents a great practical and theoretical value. An example of the lake with a tectonic basin connected with crust gaps and fractures is the Galanchozhsky Lake located in the upstream of the Gekhi River at the height of $1530 \mathrm{~m}$ A.S.L. The depth in the center of the lake reaches $31 \mathrm{~m}$, springs and atmospheric precipitation serve its sources of nourishment [13].

The aeolian lakes are located within the Tersko-Kumsky semi-desert (in deflation basins). They are characterized by rounded or oval shape and their size does not usually exceed several dozens of meters in diameter. The lakes are fed with ground waters and atmospheric precipitation. Many of them dry up in summer. The flood plain lakes belong to the valleys of the Terek, Sunzha and Dzhalka rivers thus occupying dead river channels. Their depth does not exceed $3 \mathrm{~m}$. The lakeshores are usually covered with continuous reed bed.

Chechnya has numerous mineral springs of various chemical composition: carbonated salt-alkaline, sulfatecalcium hydrosulfuric, hydrosulfuric chloride-sodium, alkaline hydrosulphuric thermal, each of which possessing critical balneological value. The first are usually met in the upper courses of the Chanty-Argun River, including Kuroysky and Baskhoysky, which were declared nature sanctuaries in 1978. As far back as $17^{\text {th }}$ century it was known about healing hot sulfur waters here. Gottlieb Schober (1717), I.K. Kirillov (Flourishing condition of the Russian state, 1927), I.A. Gyuldenshtedt (1770) and others studied them in different periods. The Bragunsky springs with typical sulfate-chloridesodium bicarbonate structure and temperature reaching $+96^{\circ} \mathrm{C}$ belong to the eastern part of the northern slope of the Bragunsky Ridge. Earlier, there was a small sanatorium with 100 beds here, which, in 1938, was closed due to the risk of depletion caused by the exploitation of Grozny oil fields. The Isti-suysky springs are located on the northern slope of the Gudermes Ridge, $12 \mathrm{~km}$ southeast from the city of Gudermes. The most producing group is the eastern group of springs with 
the total debit of about $1470 \mathrm{~m}^{3}$ a day and with the temperature within $72-75^{\circ} \mathrm{C}$. The oil field was developed in 1987 here. They can be used for treatment of the locomotion system, nervous, skin, gastrointestinal diseases. The approved reserves of $\mathrm{A}+\mathrm{B}+\mathrm{C} 1$ categories make $766 \mathrm{~m}^{3} /$ day [13].

Other mineral springs, such as Chishkinsky, ChantyArgunsky, etc. are also known for their balneological properties. The largest of them have a huge potential for health resorts. The Shandulinsky carbonic salty and alkaline spring (Narzan type) is located on the right slope of the Hakhichu River gorge and the right tributary of the Chanty-Argun River. The spring output makes 4000-6000 1/day. The Shatoi sulfatecalcium, hydrosulfuric spring (Ushkaloysky) belongs to gypsum and limestones of the Upper Jurassic. The mineral springs similar to many famous types of waters are foreseen in Benoysky, Vedensky, Elistanzhinsky and other areas of the Chechen Republic.

Alongside with hydrological and botanical objects the paleontological and stratigraphical objects of the Chechen Republic are worth paying attention. For example, a large fossil, presumably of the Upper Jurassic age, was found in Sharoysky district near the Buti village at the height of $2360 \mathrm{~m}$ A.S.L. (Fig. 4). Later, the discovery was studied by the participants of the expedition The Unknown Chechnya. The discovered object has the following size: height $-3.2 \mathrm{~m}$, circumference $-7.37 \mathrm{~m}$, diameter - $1.6 \mathrm{~m} \mathrm{[2].} \mathrm{According} \mathrm{to}$ participants of the expedition (The Unknown Chechnya, members of the Russian Geographical Society), this discovery requires further study with the assistance of paleontologists in order to define the age of enclosing rocks, object category, etc.

As noted above, some exposures to the ground surface, unique for a certain territory in terms of some parameters, may also be considered the nature sanctuaries. In this regard, the Pliensbachian deposits (Lias) located in the Chechen Republic, which are exposed in the mountains of the republic within the Chanty-Argun and Sharo-Argun interstream area on the border with Georgia, are especially noteworthy. They are composed of interstratified argillites with layers of siltstone (in the lower part), aleurolites siltstone and argillites with sand layers. The total thickness of deposits makes about $2000 \mathrm{~m}$.

It is known that the Rhaetian-Lias stage of geological development (Late Triassic-Early Jurrasic) is transitional from Hercynian geocratic to early Alpine tallasocratic cycles of tectonic movements. The same stage was marked as the most critical in the formation of the North Caucasus pattern (Rhaetian-Lias extensive peneplain). Thus, these deposits, which date back to over 185 million years, represent the beginning of the Alpine stage of geological development and deserve to be included into the list of nature sanctuaries.

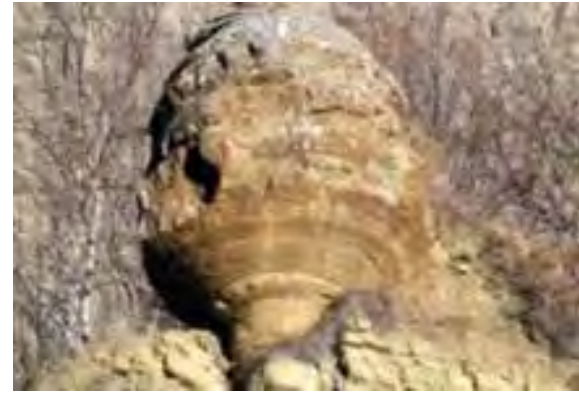

Fig. 4. Paleontological discovery.

There are many botanical objects among unique natural objects declared as nature sanctuaries by the Chechen Republic: Upper-Roshnichunsky and Roshnichunsky pine groves, sweet chestnut grove, Arnautskaya pine grove, Shalinskaya pine grove, Borozdinovsky pines, walnut, oldtimer oak, etc. Two tree species are clearly distinguished from other trees in Nozhay-Yurtovsky district $5-7 \mathrm{~km}$ from the Chechchel-He village: an oak and a beech with the trunk circumference of over $4 \mathrm{~m}$ and height of 12-15 $\mathrm{m}$. The authors suggest awarding these objects the status of nature sanctuaries.

The current state of many nature sanctuaries of the Chechen Republic, in particular, hydrological, is estimated as "unsatisfactory" despite their special status [12]. The Generalskoye Lake has completely dried up and has been excluded from the list of nature sanctuaries, the Mayorsky Lake is on the verge of extinction. This may be caused by unfavorable condition of hydraulic structures, hydrological regime of the irrigation system within the Tersko-Kumsky channel, from which water is supplied to Kapustino, Mayorskoye, Generalskoye lakes and other water objects. The following measures shall be taken to improve the condition and secure the protected areas and objects:

1) complex study to define the seasonal dynamics of key hydrological parameters (water output, temperature, mineralization, etc.), as well as other hydrochemical and hydrobiological features;

2) comprehensive study of the condition of hydrological objects located in the republic to ensure rational use of natural resources;

3) establishment of protective zones with controllable economic activity;

4) inventory of nature sanctuaries regarding their current state and conservation measures;

5) complex assessment of recreation potential of the mountain territory;

6) creation of nature sanctuaries inventory identifying the PA status, value and state;

7) establishment of PA network as an element of environmental framework of higher echelon (initially on the Northeast Caucasus scale).

Financing is an important aspect of PA sustainable development. Some scholars connect it to management efficiency highlighting the improvement of the regulatory 
framework, administrative and financial leverage for PA optimization [19]. At the same time, the traditional dependence on state source of finance for the development of protected areas failed in both developed and developing countries. Partly they shall be compensated by other sources of income: payments for ecosystem services, financing of research, developments, etc. [24].

Efficient PA management implies active interaction of all stakeholders at all levels (government, investment partners, the population, etc.) with utilization of innovative and scientific management approaches [23]. In order to ensure sustainability of protected areas over a long run (in terms of social, environmental and economic aspects) they shall "adapt" to constantly changing social and environmental conditions [16].

\section{CONCLUSIONS}

The Chechen Republic possesses a huge potential for the improvement of reserve management and development of tourist and recreation industry, which is justified by modern realities and global trends defining the main development directions of the modern world. Indeed, the optimization of the PA system is impossible without the solution of the above challenges (lack of due control over reserve management, continuous complex monitoring of its condition, noncompletion of PA inventory, etc.).

The organization of tourist and recreation activity mainly focuses on the problem of inventory, development of a register of natural attractions thus forming the basis for further development of excursion routes and programs. The study of local and regional sightseeing attractions bears a great educational value.

\section{References}

[1] V.E. Melchenko, V.R. Khrisanov, et al. "Analysis of the landscape variety of Russia, Use and protection of natural resources in Russia," No. 4, pp. 38-46, 2004.

[2] State report On environmental condition and protection of the Chechen Republic in 2017. Grozny, 2018, pp. 173.

[3] E.A. Belonovskaya, A.A. Tishkov, "Problems of preserving the natural variety of mountains in Russia (on the example of the North Caucasus)," Issues of geography. Collection of works 137: Study of mountains. Mountain regions of northern Eurasia. Development in the conditions of global changes. M.: Kodeks publishing house, pp. 107-124, 2014.

[4] Z.V. Atayev, V.V. Bratkov, "Landscape variety of protected areas of the Russian Caucasus," Geographical messenger, No. 1, pp. 4-10, 2011.

[5] I.A. Kerimov, A.A. Daukayev, et al. "Natural and recreation potential of mountains in the Chechen Republic as a factor of sustainable development of the region," Sustainable development of mountain territories, V. 9, No. 3, pp. 211-215, 2017.

[6] I.A. Bayrakov, E.B. Bolotkhanov, et al. Chechen Republic: nature, economy and ecology. Grozny, 2006, pp. 375.

[7] K.V. Chistyakov, N.V. Kaledin, et al. Mountains and people: landscape changes and ethnos of midland mountains of Russia, SPb: Publishing house of State St. Petersburg University, 2009, pp. 453.
[8] M.Yu. Shishin, O.Z. Engoyan, "Formation of environmental framework - mechanism of risk reduction regarding anthropogenic impact on natural complexes," Problems of regional ecology, No. 3, pp. 100-103, 2015.

[9] N.V. Medyanik, "Recreation development of protected areas in the North Caucasian macroregion," Competitiveness in the global world: economy, science, technologies, No. 5-3(45), pp. 94-98, 2017.

[10] R.Yu. Rakhayev, T.A. Lukyanova, "Transdisciplinary aspects of ensuring sustainable development of protected areas," Sustainable development of mountain territories, V. 2 (16), pp. 67-69, 2013.

[11] S.V. Osipov, A.M. Sazykin, E.G. Somova, "To the notion of "areas of unique interest" and natural sights (on the example of the Land of the Leopard National Park), Geography and natural resources, No. 2, pp. 3340, 2018.

[12] H.R. Bolotbiyev, "Condition of wildlife reserves and monuments in the Chechen Republic," Historical-cultural and natural heritage of the people of the South of Russia, V. 2, pp. 119-128, June 2009.

[13] Kh.Sh. Zaburayeva, Asl.A. Daukayev, "Hydrorecreation potential of the Chechen Republic," Grozny natural-science bulletin, V. 2, No. 2, pp. 1521, 2016.

[14] Kh.Sh. Zaburayeva, E.V. Krasnov, "Emerald network of protected areas," Bulletin of BFU named after I. Kant, No. 7, pp. 121-129, 2015.

[15] A.B. Gurung et al. "Global change and the world's mountains: Research needs and emerging themes for sustainable development," "Mountain Research and Development, No. 32, pp. 47-54, 2012.

[16] G.S. Cumming, C.R. Allen, N.S. Ban et al., "Understanding protected area resilience: a multi-scale, social-ecological approach," Ecological Applications, V. 25, No. 2, pp. 299-319, 2015.

[17] H. Hartwell, C. Willis, S. Page, A. Ladkin, A. Fyall, A. Hemingway, "Progress in tourism and destination wellbeing research," Current Issues in tourism, V. 21, No. 16, pp. 1830-1892, 2018.

[18] H.P. Possingham, L.R. Gerber, "Ecology: The effect of conservation spending," Nature, V. 551, No. 7680, pp. 309-310, 2017.

[19] J.E. Watson, N. Dudley, D.B. Segan, M. Hockings, "The performance and potential of protected areas," Nature, V. 515, No. 7525, pp. 67-73, November 2014.

[20] J.F. Marion, Y. Leung, H. Eagleston, Burroughs, "A review and synthesis of recreation ecology research findings on visitor impacts to wilderness and protected natural areas," Journal of Forestry, V. 114, Iss. 3, pp. 352-362, May 2016.

[21] J.V. Nikolaeva, N.M. Bogoliubova, S.S. Shirin, "Ecological tourism in the state image policy structure." Experience and problems of modern Russia, Current Issues in tourism, V. 21, No. 5, pp. 547-566, 2015.

[22] M.F. Price et al., Mountain geography: physical and human dimensions, Berkeley: University of California Press, 2013, pp. 378.

[23] Partnership for protection: new strategies for planning and management for protected areas, 2nd ed., ed.: S. Stolton, N. Dudley, London, 2014, pp. 306.

[24] P.A. Whitelaw, B.E.M. King, D. Tolkach, "Protected areas, conservation and tourism - financing the sustainable dream," Journal of sustainable tourism, V. 22, Iss. 34, pp. 584-603, January 2014.

[25] R.I. Hornoiu, M.A. Padurean, A.M. Nica, L.G. Maha, "Tourism consumpion behavior in natural protected areas," Amfiteatru Economic journal, V.16, No. 8, pp. 1178-1190, 2014.

[26] S.N. Bobylev, E.N. Bukvareva, A.A. Danilkin et al. "Ecosystem services of Russia: Prototype National Report." V. 1, Moscow: BBC Press, 2018, pp. 115.

[27] U. Huber, H. Bugmann, M. Reasoner, Global Change and Mountain Regions: An Overview of Current Knowledge, Dordrecht, Netherlands: Springer, 2005, pp. 650 . 